cantaloupe, yellow to reddish-orange in colour, with a sweet musky flavour. The fruits, which vary in size from a few ounces to $25 \mathrm{lb}$. in weight, contain 5-6 per cent of sugar, no starch, and appreciable amounts of vitamins $\mathrm{A}, \mathrm{B}$ and $\mathrm{C}$. The proteolytic enzyme papain, which also occurs in the fruit, is used in many commercial products as an aid to digestion. Numerous food and drink products are being made from the fruit pulp. The plant will bear for three or four years, but is treated commercially as an annual, since the finest fruit is obtained in the first year. Both monœecious and diœeious plants occur, which makes standardization difficult; but breeding work is being carried out to establish uniform strains.

\section{Poultry Rations in War-time}

Commercial poultry-rearing has reached a high state of efficiency, and part of that efficiency is expressed in a standardized ration, in which only food ingredients are used which have been proved to be best suited for their purpose. Under war conditions the accustomed standardized ration must be given up, since the amount and nature of feeding stuffs available for livestock becomes restricted, partly because of a reduction in imported supplies and partly because of the wider use of home-grown cereals for human consumption. Poultry-keepers are urged to exercise the greatest economy in the use of such imported materials as maize, and in order that the accustomed ration may be replaced by satisfactory substitutes the Ministry of Agriculture and Fisheries has issued, as one of its "Growmore" Leaflets (No. 14), a summary account of materials which may be used in rearing, growing or breeding rations. The list includes thirty-one different food materials, and the feeding value and method of using each stuff is stated briefly. Single copies of the leaflet-"Poultry Rations in War Time"- may be obtained free of charge and post paid on application to the Secretary, Ministry of Agriculture and Fisheries, 10 Whitehall Place, L.ondon, S.W.1.

\section{Birds of the Fenland}

Changes in the kind and distribution of the animals of the countryside which have been brought about by the progress of civilization are greater than is generally supposed, although often they are difficult to trace in detail. A short account of such changes as they have affected birds in the Fenland appears in the winter issue of Bird Notes and News (p. 198), the journal of the Royal Society for the Protection of Birds. In it Francis E. R. Peach, having quoted some early references to the bird-life, compares the earlier fauna with that of the present day, and shows that the general trend in the Fen area has been in the direction of a decline in ducks, geese, waders and birds of prey as drainage proceeded, and an increase in small birds such as linnets, yellow buntings and skylarks which now occupy the reclaimed marsh lands. Surely it is an omission that in dealing with the bird-history of this region the author does not refer to the invaluable "Early Annals of Ornithology", by the late J. H. Gurney, himself a Norfolk man.

\section{Dutch Biology}

A. VAN LEEUWENHOEK is known to every biologist as the name of a most eminent Dutch man of science, but we doubt whether many know that it is also the name of a worthy journal of Dutch microbiology, in spite of the fact that five volumes of it have already been published. This is in large measure due to its having appeared in the Dutch language, which has prevented its being read by more than a few English workers. We are glad to welcome its appearance in a new form. The editors and the Board of the Netherlands Society of Microbiology who are responsible for it have appreciated this difficulty, and from volume 6, No. 1, January 1940, it appears under the title Antonie van Leeuwenhoek, Journal of Microbiology and Serology, with English, French and German as the official languages. Thus the present number contains seven papers, five in English, one in French and one in German. Its pages are thrown open to workers of any nationality, and the editors hope that, in spite of the present inauspicious conditions, it will serve a wider public.

\section{Demography of England and Wales}

In the third quarter of $1939,161,201$ live births were registered, or 3,119 more than the number recorded in the corresponding quarter of 1938. Of the total 6,458 were illegitimate, or ${ }^{*} 13$ less than in the third quarter of 1938 . The deaths numbered 103,170 , and were 17,263 less than in the preceding quarter, but 568 more than in the third quarter of 1938. The mortality of infants under one year of age was equal to 39 per thousand registered live births. This rate is 8 per thousand below the average of the ten preceding third quarters and is the lowest quarterly rate ever recorded. The number of persons married in the third quarter of 1939 was 304,716 , an increase of 72,084 on the number in the corresponding quarter of 1938. This number corresponds to an annual rate of 29.3 per thousand of the estimated mid-year population for 1938, and is the highest rate yet recorded.

\section{X-Ray Photography of the Renal System}

In order that X-ray photographs of the renal pelvis and ureters may be obtained, it is necessary to employ a substance which, after injection into the veins, is excreted by the kidneys and is opaque to the rays, so that a shadow picture of the excretory apparatus of the kidneys may be obtained; further, such a substance must have no harmful effect. A new preparation has been introduced by Glaxo Laboratories, Ltd., under the name of "Pyelectan", which it is stated possesses the necessary properties in marked degree. Chemically, it is the sodium salt of a complex iodine-containing dicarboxylic acid, the iodine content being $\mathbf{5 1 . 5}$ per cent. Pyelectan is claimed to have a low toxicity and to be generally well tolerated, rapidly excreted by the kidneys and yielding a dense and well-defined shadow in the renal pelvis and ureter. 